\title{
繊維複合材料の界面強度評価
}

\author{
荻原慎二*1, 鹿島彰浩*2, 五十嵐雄一 ${ }^{* 2}$ \\ 小柳潤*3, 渡辺賢- ${ }^{* 4}$, 上野一郎 ${ }^{* 1}$
}

\section{Evaluation of Interfacial Strength in Fiber Reinforced Composite}

\author{
Shinji Ogihara ${ }^{* 3}$, Akihiro Kashima, Yuichi Igarashi, Jun Koyanagi, Kenichi \\ Watanabe and Ichiro Ueno
}

*3 Department of Mechanical Engineering, Tokyo University of Science 2641 Yamazaki, Noda, Chiba 278-8510, Japan

\begin{abstract}
Glass/epoxy interfacial tensile strength is investigated by the cruciform specimen method. A cruciform specimen which has large width only around fiber embedded in transverse direction can potentially prevent the stress singularity problem. The cruciform specimen geometry is first discussed by means of finite element analysis considering experimental conditions. Transverse tensile test is conducted and interfacial debonding which initiates at the middle of specimen not at edge is observed using the cruciform specimens. The interfacial tensile strength can be obtained by the value of stress concentration factor at interface times specimen stress. The location at which the debonding initiates is discussed and the validity of the evaluation method in this study is verified on an assumption that interfacial tensile strength is as high as or lower than interfacial shear strength.
\end{abstract}

Key Words : Composite Materials, Interfacal Debonding, Glass Fiber, Epoxy Resint

\section{1. 緒富}

繊維強化複合材料において, 繊維とマトリック ス間の界面は複合材料の力学的特性に重要な役割を 果たしている.よって繊維強化複合材料をいっそう 優れた材料として活用するためには，界面のより高 精度な評価が必要である. 界面特性を評価する手法 として，様々なものが用いられている.このうち， Cruciform 試験片を用いた界面の引張強度を求める 方法は端面での忍力特異性の影響を避ける事に特徴 がある 1 3).

本研究では, GF を繊維, エポキシをマトリック スとしたモデル材料について Cruciform 試験片の有 用性を実験的及び解析的に検証することを目的とす る. すなわち, Cruciform 試験片及び，通常の試験片 (Straight 試験片)の界面はく離発生, 進展挙動を実験 的に明らかにする．また，有限要素法を用いた応力

\footnotetext{
${ }^{* 1}$ 正員, 東京理科大学（广278-8510 野田市山崎 2641）

" 東京理科大学大学院, ${ }^{3}$ 正員, JAXA, ${ }^{4}$ 三菱レイヨン

E-mail: ogiahra@rs.noda.tus.ac.jp
}

解析を行う.

\section{2. 実 験 方 法}

実験には，引張荷重方向に直角な方向に繊維を持つ 単繊維複合材料を用いた. 本研究では繊維に GF（直 径 $13 \mu \mathrm{m}$ ) ，マトリックス(エポキシ)にはエピコート 828 を主剤にTETA（Triethylenetetramine）を硬化剂 にしたものを用いた. 訌験片形状としては, Straight 試験片と Cruciform 試験片を用意した.

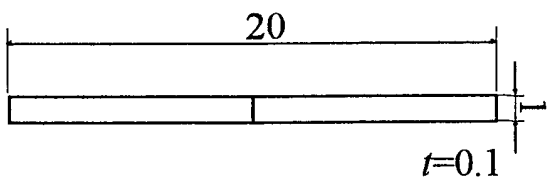

(a) Straight specimen

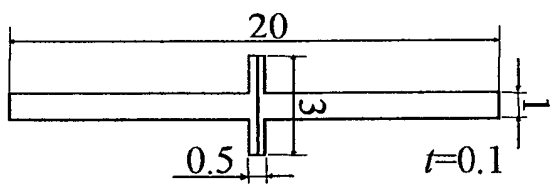

(b) Cruciform specimen

Fig.1 Schematic of specimens

(a) Straight specimen and (b) Cruciform specimen 
Fig.1にそれぞれの試験片形状を示寸.それぞれの 試験片について, 引張試験を光学顕微鏡のステージ に取り付けた小型負荷装置を用いて行った. 負荷過 程における界面はく離発生, 進展のプロセスを光学 顕微鏡により観察した．瀻維から反射される光を強 調するために繊維に垂直に両端から光を当てた. 引 張速度は $0.05 \mathrm{~mm} / \mathrm{min}$ で行った.

\section{F E M 解 析}

実験で用いた試験片形状での忘力分布を FEM 解析

(MSC.Marc.) によって調べた. Cruciform 試験片の モデル図を Fig.2に示す。詿験片は $x, y, z$ 軸に対称 な形状であるため, $1 / 8$ モデルにし，応力勾配の大 きい領域である端面と界面の周辺は要素を細かく設 定した. 要素は 8 節点立体要素を使用し，線形弾性 問題として解析した. 拘束条件はそれぞれの対称面 に拘束し, $y$ 方向に $1 \%$ のずみをモデルの上部に与 えた. 解析に用いた材料特性と要素数を Table1 に示 す.

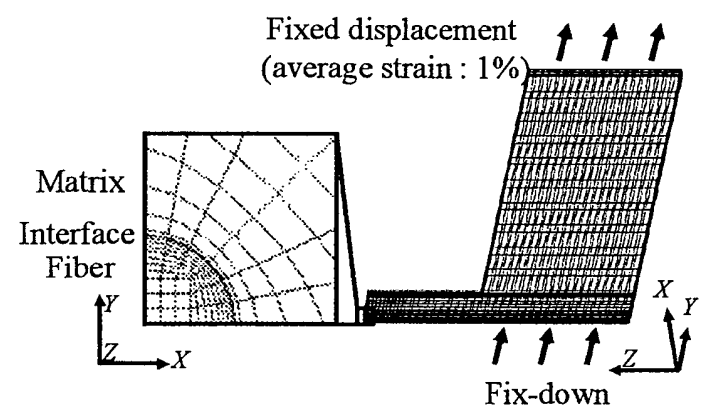

Fig.2 Schematic of a finite element analysis models

Table 1 Material properties and number of elements Young's modults Poisson's ratio Number of elements

\begin{tabular}{ccccc} 
& \multicolumn{2}{c}{ Young's modults Poisson's ratio } & \multicolumn{2}{c}{ Number of elements } \\
$E(\mathrm{GPa})$ & $v$ & Straight-GF Cruciform-GF \\
\hline GF & 70 & 0.2 & 1026 & 1995 \\
Epoxy & 4.28 & 0.42 & 3510 & 5325 \\
\hline
\end{tabular}

\section{4 実験結果および考察}

4.1 引張試験 Fig.3 及びFig.4にそれぞれ Straight 試験片及びCruciform 試験片で観察された界面はく 離発生, 進展の状態を示す. Straight 試験片では, Cruciform 圾験片に比較して低応力で端面からはく 離が発生し, 応力の增大とともに進展していく様子 が観察された. Cruciform 試験片では Straight 試験片 に比較し, 高応力ではく離が発生するが, その際, 試験片端面からの発生ではないことが確認できた. また, 発生後のはく離の進展は Straight 試験片に比 較して急激であった。
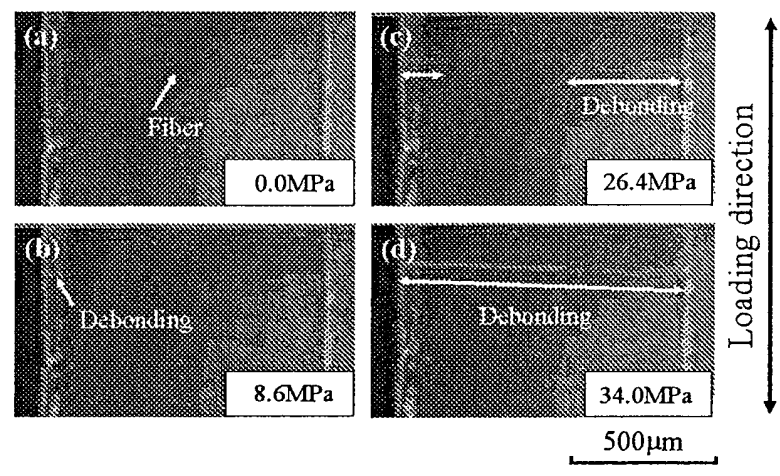

Fig.3 Debonding initiation and progress in a Straight specimen
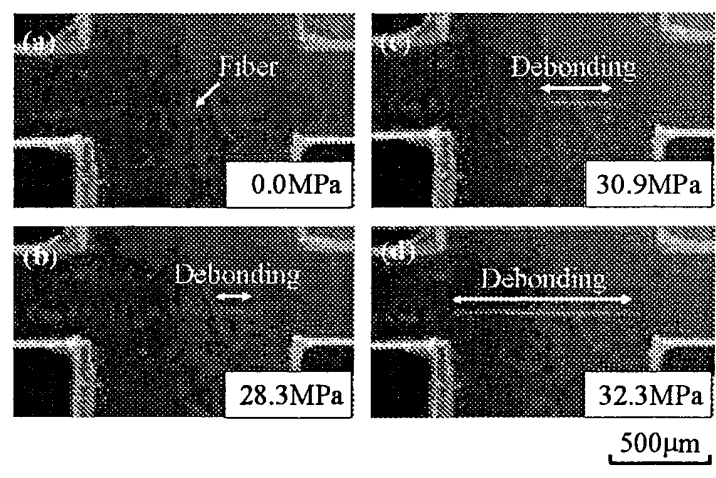

Fig.4 Debonding initiation and progress in a Cruciform specimen

4.2 FEM解析 Fig.5 は Straight 試験片及び

Cruciform 試験片についての界面垂直応力の緎維方 向での変化を示す. 界面垂直応力は試験片平均応力 (Specimen average stress と呼ぶ) によって正規化し た值（応力比と呼ぶ）を使用している. Straight 試験 片では，試験片端面での応力特異性の影響を受け， 試験片端面付近では応力が非常に大きくなっている ことがわかる. また Cruciform 試験片では，試験片 端面での応力がゼロに近く, Straight 試験片のように 端面での応力特異性の影響を受けないことが窥える。 これより実験で得られたはく離発生挙動が証明され る. また Cruciform 試験片での応力比は中央部分で 1.46 となった. よって, はく離発生時の平均㐫力に この応力比をかけることで, はく離発生時の界面垂 直応力(界面引張強度)を求めることができると考え られる. Fig.6に実験により得られた，はく離発生時 の Straight 試験片の試験片平均応力, Cruciform 試験 片の平均応力及びそれに応力比をかけて求めた界面 垂直応力を示す．それぞれの平均值は $10.9 \mathrm{MPa}$, 
30.8MPa，45.5MPa となった. これより，この系で の界面引張強度は $45.5 \mathrm{MPa}$ と推定される。

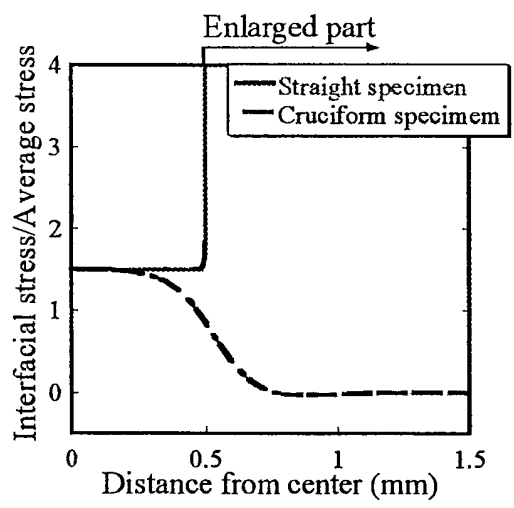

Fig.5 Relation between interfacial stress/specimen average stress

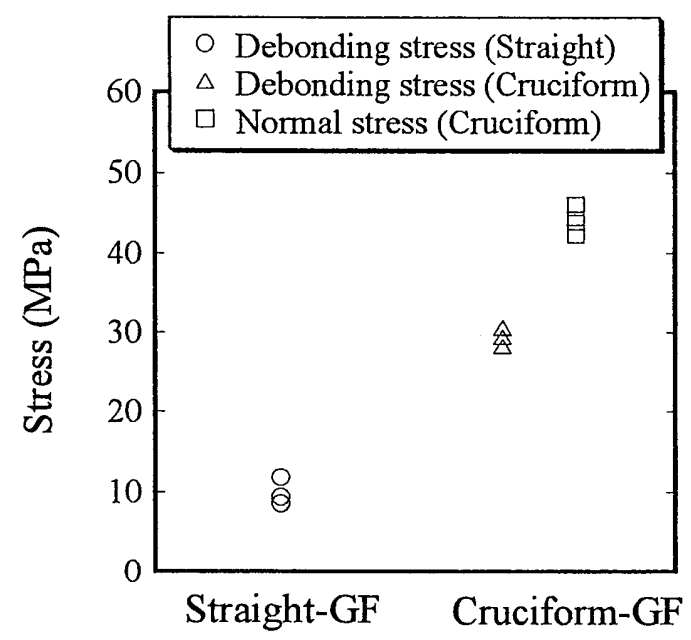

Fig.6 Debonding initiation stress and modified stress values by the stress ratio

\section{5 結 言}

GF/Epoxy モデル複合材料を用いて界面はく離の 発生, 進展挙動を観察し, Straight 試験片及び Cruciform 試験片におけるそれらの差異を実験的に 明らかにした. また, FEM解析により Cruciform 試 験片を用いることで Straight 試験片にあるような端 面の応力特異性影響を避け, 界面の引張強度を評価 できることを示した.

\section{参 考 文 献}

1) G.P. Tandon, et al., Composites Science and Technology, 60, (2000), 2281-2295.

2) D.B. Gundel, et al., Scripta Metallurgica et Materiallia, 33, 12, (1995), 2057-2065.
3) B.S. Majumdar, et al., J.Am.Ceram.Soc., 81, 6, (1998), $1600-1610$ 